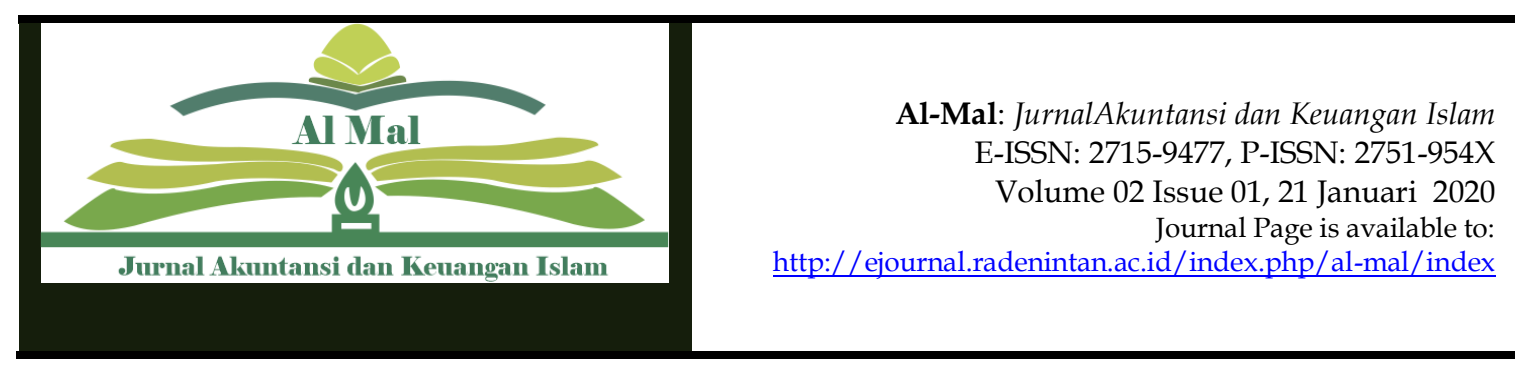

\title{
Analisis Pengaruh Variabel Makro Terhadap Return Indeks Saham Syariah Di Indonesia: Studi Pada Fenomena Perang Dagang Global
}

\author{
Rizaldi Yusfiarto $^{1 *}$, Galuh Tri Pambekti ${ }^{2}$ \\ 1*2Departement of Economics, Faculty of Economics and Business, \\ Universitas Islam Negeri Sunan Kalijaga, Indonesia
}

\begin{tabular}{l}
\hline \multicolumn{1}{c}{ ARTICLE INFO } \\
\hline Article history: \\
Received 18-01-2020 \\
Revised 18-01-2020 \\
Accepted 18-01-2020 \\
Available 21-01-2020 \\
Revised (1) 16-05-2022 \\
Revised (2) 11-07-2022 \\
Accepted 11-07-2022 \\
Revised Available 17-07-2022 \\
\hline Kata Kunci: \\
Jakarta Islamic Index, Nilai Tukar \\
CNY / IDR, Nilai Tukar USD / IDR, \\
Inflasi, Minyak Mentah WTI, minyak \\
mentah ICP \\
\hline
\end{tabular}

Paper type: Research paper

Please cite this article: Yusfiarto, R., \& Pambekti, G. T. "Analisis Pengaruh Variabel Makro Terhadap Return Indeks Saham Syariah Di Indonesia: Studi Pada Fenomena Perang Dagang Global" Al-Mal: Jurnal Akuntansi dan Keuangan Islam [ONLINE], Volume 01 Number 01 (Januari 21, 2020)

\section{Cite this document:}

Al-Mal 2th edition

*Corresponding author
e-mail: rizaldi.yusfiarto@uin-
suka.co.id

Page: $115-134$

\begin{tabular}{l}
\hline \multicolumn{1}{c}{ ABSTRAK } \\
\hline Penelitian ini bertujuan untuk membuktikan \\
Perkembangan investasi di pasar modal syariah, \\
terutama Jakarta Islamic Index (JII) sebagai \\
persentase mengalami perkembangan yang \\
signifikan, itu karena indeks Islam menggunakan \\
prinsip-prinsip dan prosedur Islam. Metode \\
pendekatan yang digunakan yaitu metode \\
kunatitatif dengan menggunakan alat olah data \\
software Eviews 9. Hasil penelitian menunjukan \\
bahwa Fenomena perang dagang antara Amerika \\
Serikat dan China memiliki dampak pada fluktuasi \\
variabel makro, yang secara empiris dapat \\
mempengaruhi pertumbuhan indeks syariah. \\
Keterbatasan pada penelitian ini untuk \\
menganalisis dampak perubahan karena sentimen \\
perang dagang. variabel ekonomi makro yang \\
digunakan dalam penelitian ini adalah USD / IDR \\
nilai tukar, nilai tukar CNY / IDR, inflasi, minyak \\
mentah WTI dan minyak ICP mentah. analisis \\
regresi otomatis ini menggunakan studi vektor \\
teknik (VAR). uji stasioneritas menggunakan uji \\
Augmented Dickey-Fuller (ADF Test) dan Uji \\
Philips-Perron sehingga dapat membuka peluang \\
untuk peneliti lainnya untuk melakukan penelitian \\
ulang dengan variabel lainnya. Implikasi pada \\
penelitian ini yaitu untuk melihat Fluktuasi kondisi \\
makro ekonomi akibat sentimen perang dagang \\
global yang telah telah menunjukan pengaruh yang \\
nilai signifikansinya sangat tinggi, karenanya \\
diperlukan diagnostik lebih mendalam terhadap \\
fenomena tersebut.
\end{tabular}


ABSTRACT: This study aims to prove the development of investment in the Islamic capital market, especially the Jakarta Islamic Index (JII) as a percentage experienced a significant development, it is because the Islamic index uses Islamic principles and procedures. The approach method used is the quantitative method using the Eviews 9 software data processing tool. The results show that the phenomenon of the trade war between the United States and China has an impact on fluctuations in macro variables, which empirically can affect the growth of the sharia index. The limitations of this study are to analyze the impact of changes due to trade war sentiment. Macroeconomic variables used in this study are USD/IDR exchange rate, CNY/IDR exchange rate, inflation, WTI crude oil and crude ICP oil. This automatic regression analysis uses the vector study technique (VAR). stationarity test using the Augmented Dickey-Fuller test (ADF Test) and the Philips-Perron test so that it can open up opportunities for other researchers to conduct re-study with other variables. The implication of this research is to see fluctuations in macroeconomic conditions due to global trade war sentiment which has shown a very high significance value effect, therefore more indepth diagnostics of this phenomenon is needed.

Keywords : Jakarta Islamic Index, CNY / IDR Exchange Rate, USD / IDR Exchange Rate, Inflation, WTI Crude Oil, ICP Crude Oil

\section{PENDAHULUAN}

Investasi pasar modal memiliki dampak terhadap kemakmuran ekonomi, dikarenakan salah satu parameter pertumbuhan ekonomi suatu negara adalah bursa saham yang dinamis (Hsing, 2008). Selain itu, globalisasi dan pertumbuhan yang lebih luas pada perdagangan investasi terintegrasi dengan pasar keuangan internasional dan partisipasi dari investor luar negeri memiliki keterkaitan dengan pasar saham global dan pasar nilai tukar luar negeri serta hubungan antara nilai tukar dan fluktuasi pasar saham (Annisa Masruri Zaimsyah dkk, 2020). Perubahan variabel makroekonomi memiliki dampak yang berbeda pada berbagai spektrum ekonomi. Harga saham mencerminkan ekspektasi terhadap kinerja perusahaan di masa yang akan datang (Edri Fauzan \& Khairunnisa, 2019). Ada beberapa jenis indeks pada pasar modal dunia, dikarenakan hampir setiap negara memiliki indeks saham, bahkan banyak negara memiliki lebih dari satu indeks saham.

Contohnya Indonesia memiliki memiliki Indeks Harga Saham Gabungan (IHSG), Jakarta Islamic Index (JII), dan Indeks Saham Syariah Indonesai (ISSI), negara Jepang mempunyai indeks syariah Dow Jones Islamic Market Index 
Japan (DJIJP) dan negara Amerika Serikat memiliki Dow Jones Islamic Market US (IMUS), serta negara Eropa mempunyai Dow Jones Islamic Market Europe (DJIEU) (Emet Chotib \& Nurul Huda, 2019). Perdagangan pada pasar modal konvensional maupun syariah memiliki tingkat return dan resiko yang berbeda, perkembangan investasi pasar modal syariah menunjukan peningkatan yang signifikan, seiring perkembangan indeks yang ditunjukan dalam JII (Jakarta Islamic Index).

Apabila dibandingkan dengan IHSG (Indeks Harga Saham Gabungan) memang nilainya tidak terlalu besar, akan tetapi memiliki prosentase kenaikan lebih besar. Alasan yang melandasi fenomena tersebut antara lain dikarenakan pasar modal syariah menggunakan asumsi, instrument, prinsip dan prosedur bersumber kepada epistimologi islam (Auliyah and dan Hamzah, 2006). Selain itu, munculnya produk syariah di pasar modal pada mulanya berawal dari keinginan untuk mengakomodasi kebutuhan umat Islam yang ingin melakukan investasi dengan prinsip syariah (Irfan Syauqi Beik \& Sri Wulan Fatmawati, 2014). Perusahaan dapat mengembangkan modal dengan cara menarik investor yang ingin berinvestasi dengan membeli saham perusahannya semakin banyak investor yang membeli saham perusahaan maka semakin banyak pula tambahan dana yang akan diperoleh (Nabila Nurliandini dkk, 2021). Kehadiran pasar modal di suatu negara dianggap sangat penting terkait perannya sebagai penggerak perekonomian nasional yang berfungsi menyediakan fasilitas untuk mempermudah perusahaan dan emiten mendapatkan dana serta bagi investor untuk menyalurkan dananya dengan harapan mendapat bagi hasil atas dana yang disalurkannya (Martien Rachmawati \& Nisful Laila, 2015).

Pasar saham syariah sangat berkaitan erat dengan variabel ekonomi makro, return dalam investasi pasar modal syariah sangat dipengaruhi (Barakat, Elgazzar and Hanafy, 2015). Menurut Direktur Utama BEI sebanyak 65\% jumlah saham yang ada di BEI merupakan saham syariah, sedangkan untuk kapitalisasi pasarnya sebanyak 55\% dikuasai oleh saham syariah, dan 56\% nilai 
transaksi yang ada di bei tersebut juga dikuasai oleh saham-saham syariah (Listya Endang Artiani \& Citra Utami Puspita Sari, 2019). Investor memiliki beberapa alternatif untuk menginvestasikan dananya mulai dari asset riil hingga dalam bentuk sekuritas. Investasi adalah komitmen atas sejumlah dana atau sumber daya lainnya yang dilakukan pada saat ini dengan tujuan memperoleh sejumlah keuntungan di masa mendatang (Nur Fadila \& Lilis Ardini, 2019).

Tahun 2018 sampai dengan tahun 2019 perekonomian global mengalami guncangan dengan adanya perang dagang antara Amerika dan China, Amerika memberlakukan bea impor produk China sebesar 200 milliar US dollar dan China membalas menaikan bea masuk produk asal Amerika senilai 60 milliar US dollar pada 1 Juni 2019. Tahun 2019 bukan-tahun yangubaikubagiureksadanausahamusyariah. Pasalnya, pada setiap bulan kinerja produk investasI yang satu ini masih terus mencatatkan penurunan, dapat dilihat dari dampak kondisi makro ekonomi (Hani Nurrahmawati dkk, 2021). Menurut CNN Indonesia akibat sentimen perang dagang yang terjadi antar kedua negara, indeks-indeks dalam bursa Wall Street terkoreksi dalam. Indeks Dow Jones Industrial Average melemah 617,38 poin (2,38\%), Nasdaq Composite melemah 3,41\% diakhir perdagangan, Indek Shanghai melemah 1,1\% ke level 2872,83, dan Indeks Hangseng terkoreksi melemah 2,1\% ke level 27.951, 12 (14/05/2019). Sentimen negatif tersebut juga berimbas terhadap nilai tukar Rupiah terhadap US Dollar, tercatat di tanggal 14 Mei 2019 Rupiah bergerak diangka 14.425 sampai dengan 14.455 per US Dollar (melemah 0,45\%). Sentimen ini juga merdampak signifikan terhadap harga minyak dunia. Mengutip pernyataan Reuters harga minyak West Texas Intermediete (WTI) mengalami pelemahan sebesar 1,94\% menjadi 53,63 US Dollar per barel, sedangan untuk harga minyak berjangka Brent tercatat mengalami pelemahan sebesar 1,45 \% menjadi 58,94 US Dollar per barel. Selama periode Mei 2019 prosentase pelemahan harga minyak mencapai 22\% dari posisi tertigginya bulan April 2019, kemudian harga minyak Brent mengalami penurunan yang 
signifikan sebesar 9\%, sentimen tersebut setelah pengumuman presiden Amerika memberikan pernyataan bahwa akan mengaplikasikan tarif lebih bagi barang impor asal China (www.cnnindonesia.co.id).

Berdasarkan fenomena yang terjadi, menarik dilakukan penelitian berdasarkan dampak perubahan yang terjadi didalam ekonomi makro terhadap indeks syariah akibat sentimen perang dagang gilobal Amerika dengan China. Beberapa penelitian yang telah dilakukan menunjukan adanya ketidakkonsitenan dan gap terkait hasil pengujian terhadap variabel makroekonomi dengan indeks saham. Kebanyakan industri yang bergerak dalam sektor riil juga melakukan listing di pasar modal untuk menambah aliran modal mereka. Sehingga dapat dikatakan nilai dari industrial production juga mencerminkan tingkat aktivitas yang terjadi di perusahaan tersebut (Aurora Nur Firdausi dkk, 2016). Pergerakan mobilitas dana menunjukkan tinggi intensitas perusahaan yang memanfaatkan pasar modal sebagai sumber untuk mendapatkan dana. Perusahaan yang mendapatkan suntikan dana melalui penjualan saham, obligasi dan bentuk surat berharga lain akan mendapatkan dana segar untuk memenuhi input produksi (Heri Sudarsono, 2018).

Hasil temuan menunjukan bahwa harga minyak dunia berpengaruh positif terhadap bursa saham, bahwa inflasi mempunyai pengaruh positif terhadap indeks sektoral dan perubahan nilai kurs memiliki pengaruh signifikan negatif terhadap indeks syariah di Malaysia (Lin, Fang and Cheng, 2010; Nguyen, 2011; Hussin et al., 2013; Law and Ibrahim, 2014). Pertanyaan yang muncul dan dapat dianalisis dalam penelitian ini sebagai berikut:

1. Bagaimana pengaruh perubahan kurs USD/IDR terhadap return JII (Jakarta Islamic Index) di Bursa Efek Indonesia?

2. Bagaimana pengaruh perubahan kurs CNY/IDR terhadap return JII (Jakarta Islamic Index) di Bursa Efek Indonesia?

3. Bagaimana pengaruh perubahan inflasi terhadap return JII (Jakarta Islamic Index) di Bursa Efek Indonesia? 
4. Bagaimana pengaruh perubahan crude oil WTI terhadap return JII (Jakarta Islamic Index) di Bursa Efek Indonesia?

5. Bagaimana pengaruh perubahan ICP (Indonesian Crude oil Price) terhadap return JII (Jakarta Islamic Index) di Bursa Efek Indonesia?

\subsection{Definisi Perubahan Kurs Terhadap}

Return JII (Jakarta Islamic Index)

Perubahan kurs merupakan bidang yang sampai sekarang ini masih sering menjadi perdebatan, untuk itu hubungan antara nilai tukar dengan variabel fundamental makro masih harus dianalisis lebih dalam (Kurihara, 2012). Nilai tukar atau kurs mata uang menjadi catatan harga pasar dari mata uang asing dalam harga mata uang domestik, yaitu harga mata uang domestik dalam mata uang asing (Fitri Rahmawati \& Nirmala Baini, 2019). Kurs itu sendiri dapat dijadikan parameter kekuatan nilai mata uang suatu negara bila dibandingkan dengan mata uang negara lain (Beckmann, Belke and Kühl, 2011).

Nilai tukar suatu mata uang merupakan hasil interaksi antara kekuatan permintaan dan penawaran yang terjadi di pasar valuta asing (Fifi Afiyanti Tripuspitorini, 2021). Kondisi dimana suatu negara mengalami kondisi apresiasi memungkinkan terjadinya peningkatan impor dan sebaliknya dimana suatu negara mengalami depresiasi maka memungkinkan meningkatnya ekspor (Musthafa, 2017). Terkait ketidakpastian kondisi ekonomi global, hal tersebut secara eksplisit dapat menjadi faktor penentu pertumbuhan industri syariah di Indonesia (Aisiyah, 2013; Widad and Hadjer, 2018). Negara China menurut data merupakan negara terbesar bagi importir Indonesia, sehingga kebijakan internal pemerintahnya sangat berpengaruh signifikan terhadap kondisi ekonomi didalam negeri. Semenjak kurs yuan diterbitkan di Indonesia, hal tersebut memberikan dampak penggunaan mata uang yuan sebagai alat tukar bagi industri di Indonesia dalam melakukan perdagang internasional dengan industri di China (Yudianto and Muharam, 2018). Kurs dapat ditentukan oleh pemerintah seperti pada negara-negara yang memakai sistem 
fixed exchange rates ataupun ditentukan oleh kombinasi antara kekuatankekuatan pasar yang saling berinteraksi serta kebijakan pemerintah seperti pada negara-negara yang memakai sistem flexible exchange rate (Desy Trishardiyanti Adiningtyas, 2018). Menguatnya nilai tukar (kurs) mata uang suatu negara terhadap negara lain dapat menandakan bahwa keadaan ekonomi negara tersebut sedang baik. Demikian pula sebaliknya, perubahan nilai tukar (kurs) mata uang suatu negara yang cenderung melemah seringkali di pandang negatif (Yoyok Prasetyo dkk, 2019).

\subsection{Definisi Perubahaban Inflasi Terhadao Return JII (Jakarta Islamic Index)}

Secara umum diterima, ketidakpastian terhadap inflasi akan mendistorsi mekanisme harga dan efisiensi alokasi sumber daya (Payne, 2008). Ketika ekspektasi terhadap inflasi meningkat, akan berdampak kepada kenaikan tingkat nominal suku bunga ( $\mathrm{Wu}, 2012)$. Ketidakstabilan tingkat inflasi memiliki dampak atas ketidakpastian pasar keuangan global dan berpotensi terjadinya depresiasi nilai tukar rupiah akibat kenaikan suku bunga kebijakan global (Syaista Nur dan Nur Fatwa, 2022). Peningkatan nominal suku bunga menciptakan tekanan kepada harga melalui keseimbangan pasar uang, jika uang yang beredar tidak berubah (Gupta and Reid, 2013). Dengan demikian kenaikan ekspektasi inflasi dapat memicu kondisi aktual inflasi dalam perekonomian (Baghestani and AbuAl-Foul, 2010). Ketika suatu negara mengalami kenaikan inflasi yang tinggi dan bersifat uncertainty (tidak menentu) maka resiko dari investasi dalam aset-aset keuangan akan meningkat dan keredibilitas mata uang domestik akan melemah terhadap mata uang global (Yudhistira Ardana, 2016). Penargetan terhadap aktual inflasi oleh bank sentral dapat dilakukan dengan menjaga ekpektasi inflasi ini, pada gilirannya mengharuskan bank sentral memahami ekosistem perdagangan, isu perokonomian dan kebijakan-kebijakan ekonomi global (Montes and Nicolay, 2015). Bagi pengusaha ekspektasi inflasi merupakan hal penting, dikarenakan secara empiris kenaikan aktual inflasi dalam suatu perekonomian dapat 
mempengaruhi tingkat daya beli (Aghekyan-Simonian et al., 2012). Penurunan tingkat daya beli ini sacara langsung berdampak kepada penurunan pendapatan perusahaan dan laba perusahaan, dengan demikian akan berpengaruh kepada minat investor untuk berinvestasi (Yudianto and Muharam, 2018). Tingkat suku bunga sebagai salah satu instrumen untuk mengendalikan inflasi. Apabila inflasi dirasakan cukup tinggi maka Bank Indonesia akan menaikkan tingkat suku bunga untuk meredam kenaikan inflasi (Hanita Yuniati, 2018).

\subsection{Definisi Perubahan Crude Oil Terhadap Return JII (Jakarta Islamic Index)}

Minyak mentah merupakan sumber energi yang memiliki banyak atribut antara lain nilai sumber daya, nilai komoditas dan implikasi keuangan (Bala and Chin, 2017). Meskipun energi yang terbaharukan terus dilakukan pengembangan selaras dengan semakin majunya ilmu dan teknologi, minyak mentah masih memegang peranan penting dalam pemenuhan sumber daya energy (Zhang and $\mathrm{Wu}, 2018$ ). Sebagai sumber energi, minyak mentah merupakan bahan baku utama untuk menunjang kegiatan produksi didalam industri "the blood of industry", secara langsung maupun tidak langsung mempengaruhi pembangunan ekonomi (Hull, 2002; Li and Zhao, 2011). Sebagai komoditas penting, kenaikan harga minyak mentah menyebabkan tekanan inflasi dan kenaikan komoditas lainnya sehingga mempengaruhi pertumbuhan ekonomi sektor riil (BenMabrouk, 2018). Dengan pendalaman secara finansial dan pemasaran, hubungan antara komoditas minyak mentah dengan pasar saham semakin dekat (Li and Zhao, 2011). Pasar saham mencerminkan tren, status operasional perusahaan dan perkembangan ekonomi suatu negara, sehingga pengaruh antara harga minyak terhadap ekonomi sektor riil dapat tercermin dalam pasar saham (Schnabel, 2011). Harga minyak berperan terhadap return suatu saham dengan dua keadaan, pertama; guncangan harga minyak dapat menyebabkan perubahan dalam arus kas, kedua; guncangan harga minyak dapat berdampak kepada tingkat diskonto yang digunakan untuk menilai ekuitas ekspektasi inflasi (Ciner, 2013). Selain itu pertumbuhan 
harga minyak juga dapat berdampak kepada arus kas suatu perusahaan, baik secara negatif maupun positif bergantung kepada apakah perusahaan memproduksi atau mengkonsumsi minyak mentah (Widad and Hadjer, 2018). Gejolak harga minyak dunia menghantui aktivitas perdagangan saham dimana iklim investasi menjadi tidak kondusif di pasar modal (Siti Aisiyah Suciningtias \& Rizki Khoiroh, 2015).

\section{METODOLOGI PENELITIAN}

Penelitian ini menggunakan sumber data yang berasal dari Bloomberg dan Reuters, selain itu sebagian data diperoleh melalui sumber-sumber website resmi lembaga yang terkait dengan penelitian ini seperti Bank Indonesia, Otoritas Jasa Keungan (OJK), Kementerian ESDM dan CNN Indonesia. Sampel yang dianalisis dalam penelitian adalah (1) Return Jakarta Islamic Index; (2) Sampel variabel makro ekonomi yang digunakan, Kurs USD/IDR, kurs CNY/IDR, Inflasi, Crude oil WTI dan Crude oil ICP. Data time series digunakan, periode data diambil dan dianalisis dari bulan januari 2016 sampai dengan bulan Desember 2018. Vector auto regression digunakan sebagai teknik analisis, kemudian data dianalisis menggunakan software Eviews 9.

\section{HASIL DAN PEMBAHASAN}

Vector Auto Regression (VAR) digunakan untuk memproyeksikan sebuah sistem dengan variabel runtut waktu dan untuk menganalisis dampak dinamis dari faktor gangguan yang terdapat dalam sistem variabel tersebut. Kriteria uji stasioneritas yaitu nilai probabilitas < a 0,05 dikatakan data stasioner. Hasil analisis menunjukan bahwa variabel USD/IDR nilai probabilitas $0,0000<a$ 0,05 , variabel CNY/IDR nilai probabilitas $0,0000<a$ 0,05, variabel inflasi nilai probabilitas $0,0000<a$ 0,05, variabel WTI nilai probabilitas 0,0000 < a 0,05, variabel ICP nilai probabilitas $0,0001<$ a 0,05 , variabel JII nilai probabilitas 0,0002 < a 0,05 (lihat tabel 2). Dapat disimpulkan bahwa data variabel 
penelitian memenuhi syarat (stasioner) sesuai dengan parameter yang diinginkan.

Tabel .1.

Uji Stasioneritas Data

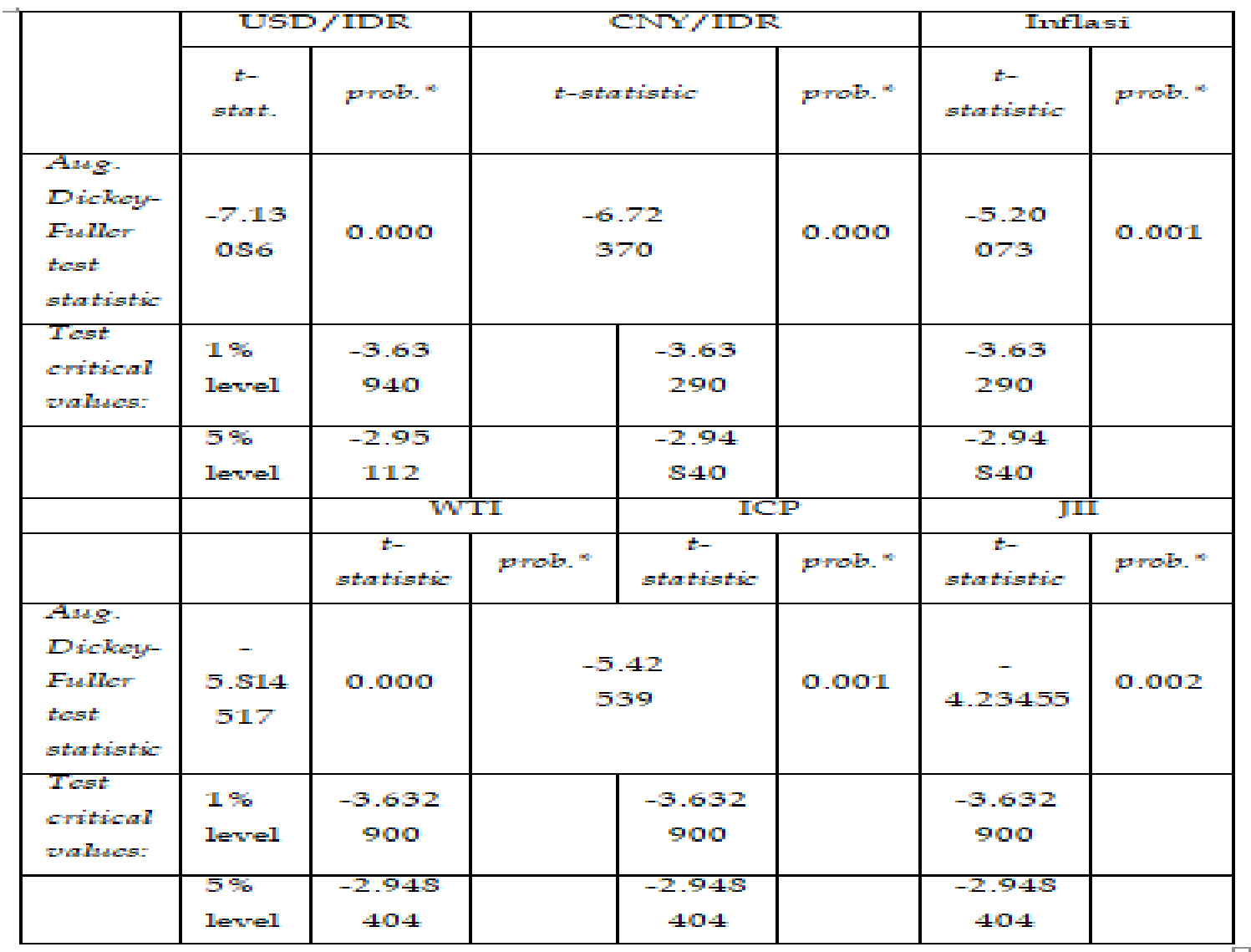

Sumber: Data yang diolah, 2019

Tabel .2.

Uji Stasioneritas Data

\begin{tabular}{|c|c|c|c|c|}
\hline Variable & Coefficient & Std. Error & t-Statistic & Prob. \\
\hline USD & -1.855 & 0.260175 & -7.130860 & 0.0000 \\
IDR(-1) & 272 & 0.003022 & 0.812212 & 0.4229 \\
\hline C & 0.002 & & 0.0000 \\
\hline CNY & -1.172 & 0.174317 & -6.723705 & 0.8045 \\
\hline IDR(-1) & 058 & 0.002678 & 0.249546 & 0.0000 \\
\hline C & 0.000 & 0.173256 & -5.200737 & 0.4620 \\
\hline INFLASI & -0.901 & 0.818818 & -0.744158 & \\
\hline (-1) & 060 & -0.609 & & \\
\hline
\end{tabular}




\begin{tabular}{|c|c|c|c|c|}
\hline & 331 & & & \\
\hline WTI(-1) & $\begin{array}{c}-0.998 \\
792\end{array}$ & 0.171776 & -5.814517 & 0.0000 \\
\hline C & $\begin{array}{c}0.014 \\
450\end{array}$ & 0.021807 & 0.662650 & 0.5122 \\
\hline $\mathrm{ICP}(-1)$ & $\begin{array}{c}-0.911 \\
981\end{array}$ & 0.168095 & -5.425393 & 0.0001 \\
\hline C & $\begin{array}{c}0.021 \\
301\end{array}$ & 0.022976 & 0.927089 & 0.3606 \\
\hline $\begin{array}{c}\text { INDEX } \\
\text { JII(-1) }\end{array}$ & $\begin{array}{c}-0.734 \\
410\end{array}$ & 0.173433 & -4.234553 & 0.0002 \\
\hline C & $\begin{array}{c}-0.180 \\
053\end{array}$ & 0.191339 & -0.941014 & 0.3535 \\
\hline
\end{tabular}

Sumber: Data yang diolah, 2019

Langkah berikutnya yaitu pemilihan lag optimal dalam pengujian VAR dengan membandingkan uji lag yang telah dilakukan. Hasil uji lag selection (lihat tabel 3): berdasarkan output menunjukkan bahwa lag yang akan digunakan adalah lag 2 karena dinilai lebih optimal dibanding Lag 1. Penilaiannya dilihat dari tanda paling banyak pada kriteria data (Yudianto and Muharam, 2018). Selanjutnya analisis uji kointegrasi, analisi uji kointegrasi penting dilakukan untuk mengetahui apakah model merupakan VAR tingkat differensi jika tidak ada stasioneritas data yang diuji (Yudianto and Muharam, 2018). Hasil dari analisis uji kointegrasi menunjukan (lihat tabel 4), seluruh variabel lolos uji kointegrasi ditandai dengan adanya tanda pada indikator "At most $1-5^{\prime \prime}$ dan ditunjukkan dengan adanya critical value seluruhnya lebih besar dari 0,05 .

Tabel .3.

Uji Kointegrasi

\begin{tabular}{|c|c|c|c|c|}
\hline Ifypotituesized & \multirow[b]{2}{*}{ Fingenormluae } & Trube & 0.05 & \multirow[b]{2}{*}{ IFxoln } \\
\hline $\mathbb{N}=-\infty \in \mathbb{E}:=$ & & Statistie & $\begin{array}{l}\text { Cuitical } \\
\text { Waluae }\end{array}$ & \\
\hline Tronge $*$ & $0.9 \pm 1925$ & 2279140 & 95.75366 & 0.0000 \\
\hline At manost $I *$ & 0.555053 & 136.405 & 69.51599 & 0.0000 \\
\hline$A t$ manost $2 *$ & 0.659513 & $7 \pm .36035$ & \pm 7.55613 & 0.0000 \\
\hline$A_{1}$ manest $3 \%$ & 0.394643 & 37.10751 & 29.79907 & 0.0060 \\
\hline At manost $4 \cdots$ & 0.361070 & 21.04551 & 15.40471 & 0.0066 \\
\hline 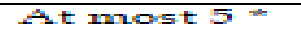 & 0.199152 & $6.710,992$ & 3.541166 & 0.0096 \\
\hline
\end{tabular}


Tabel .4.

Uji Lag Optimal

\begin{tabular}{|c|c|c|c|c|c|c|}
\hline Lag & LogL & LR & FPE & AIC & SC & HQ \\
\hline 0 & 141.6576 & NA & $1.38 \mathrm{e}-11$ & -7.97986 & $-7.710502^{*}$ & -7.888001 \\
\hline 1 & 192.9766 & 81.50665 & $5.80 \mathrm{e}-12$ & -8.880977 & -6.995473 & $-8.237966^{*}$ \\
\hline 2 & 236.3892 & $53.62733^{*}$ & $4.63 \mathrm{e}-12^{*}$ & $-9.317012^{*}$ & -5.815362 & -8.122849 \\
\hline
\end{tabular}

Sumber: Data yang diolah, 2019

Secara individual, koefisien didalam model VAR sulit diinterpretasikan, maka para ahli menggunakan analisis impuls respon. Impuls respon ini merupakan satu analisis penting di dalam suatu model VAR. Analisis impuls respon melacak respon dari variabel endogen dari dalam sistem VAR karena adanya goncangan atau shock di dalam variabel gangguan (e). Berikut adalah hasil uji Impuls Respon:

Grafik 1, Impuls Respons Variable

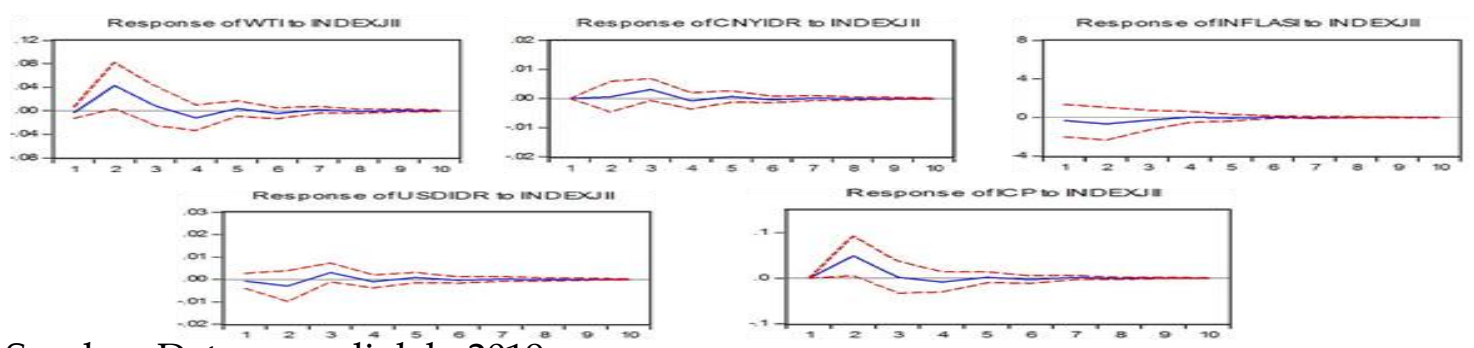

Sumber: Data yang diolah, 2019

Pada grafik diatas dapat terlihat bahwa terjadi shock pada variabel satu dengan yang lainnya.Shock yang terjadi bervariatif tidak mengarah pada satu trend tertentu. Hal ini menunjukkan bahwa terjadinya gangguan e dalam persamaan antar variabel yang diujiakan mempengaruhi variabel tersebut saat ini atau dimasa mendatang. Karena antar variabel saling memberikan shock, maka gangguan e juga dapat/akan mempengaruhi variabel-variabel yang lain.

Varian Decomposition berguna untuk memprediksi kontribusi presentase varian setiap variabel karena adanya perubahan variabel tertentu di dalam sistem VAR. Berikut adalah hasil output varian decomposition pada variabel Jakarta Islamic Index (JII) periode 1 varian Indeks JII dijelaskan oleh variabel itu sendiri sebesar 86,3\%. Pada period 2, varian Indeks JII dijelaskan 
oleh variabel itu sendiri sebesar 49,8\%. Sedangkan sisanya dijelaskan oleh variabel CNY/IDR, USD/IDR, ICP, WTI dan Inflasi.

Tabel .5.

Variance Decomposite Index

\begin{tabular}{|c|c|c|c|c|c|c|c|}
\hline \multicolumn{7}{|c|}{ Variance Decomposition of Indeks JII } \\
\hline Period & S.E. & CNY/IDR & ICP & INDEX JII & INFLASI & USD/IDR & WTI \\
\hline 1 & 0.930322 & 10.07305 & 3.610916 & 86.31604 & 0.000000 & 0.000000 & 0.000000 \\
\hline 2 & 1.294095 & 6.033396 & 18.34050 & 49.83073 & 20.40749 & 1.895198 & 3.492687 \\
\hline 3 & 1.421939 & 5.192494 & 15.97814 & 41.59897 & 17.22982 & 10.32820 & 9.672370 \\
\hline 4 & 1.460772 & 4.988361 & 15.28338 & 39.46553 & 21.29328 & 9.786572 & 9.182875 \\
\hline 5 & 1.518869 & 5.058282 & 14.45068 & 36.50705 & 22.82294 & 10.51755 & 10.64349 \\
\hline 6 & 1.565038 & 5.657483 & 13.78455 & 34.53226 & 26.09000 & 9.910310 & 10.02540 \\
\hline 7 & 1.586851 & 5.552465 & 14.82705 & 33.58941 & 26.09974 & 9.671596 & 10.25974 \\
\hline 8 & 1.621776 & 5.356528 & 15.75554 & 32.33947 & 27.32298 & 9.260275 & 9.965200 \\
\hline 9 & 1.632739 & 5.307735 & 15.56451 & 32.16617 & 27.19201 & 9.210554 & 10.55903 \\
\hline 10 & 1.636274 & 5.353369 & 15.73993 & 32.09809 & 27.07571 & 9.175181 & 10.55772 \\
\hline
\end{tabular}

\section{Sumber: Data yang diolah, 2019}

Berdasarkan output estimasi model vector auto regression dapat diambil kesimpulan bahwa variabel perubahan kurs USD/IDR berpengaruh signifikan dengan nilai probabilitas $0,0010<$ a 0,05 , variabel perubahan kurs CNY/IDR berpengaruh signifikan dengan nilai probabilitas 0,0002 < a 0,05, variabel perubahan inflasi tidak berpengaruh signifikan dengan nilai probabilitas 0,1928 > a 0,05, variabel perubahan crude oil WTI berpengaruh signifikan dengan nilai probabilitas $0,0049<$ a 0,05 , variabel crude oil ICP berpengaruh tidak signifikan dengan nilai probabilitas 0,1469 > a 0,05 dan variable independen mempengaruhi variabel dependen secara simultan dilihat dari nilai probabilitas (f-statisic) sebesar 0,0021 < a 0,05 (lihat tabel 6). 
Tabel .6.

\section{Estimasi Model}

\begin{tabular}{|c|c|c|c|c|}
\hline Waniable & Confficient & Stal. Enmor & t-Statistie & Prob. \\
\hline$C$ & -0.074439 & 0.181328 & -0.410519 & 0.6545 \\
\hline DITSDIDIE & -55.42301 & 15.05094 & -3.652362 & 0.0010 \\
\hline DICNDIDES & 57.69977 & $20.537+3$ & 4.269754 & 0.0002 \\
\hline $\begin{array}{l}\text { DIIIFLASI } \\
6-1 \mathrm{~J}\end{array}$ & -0.035656 & 0.025967 & -1.334169 & 0.1925 \\
\hline D(WNIA-Iy) & 5.536533 & 2.696129 & 2.053253 & 0.0495 \\
\hline $\mathbb{D}(\operatorname{ICP}(-\mathbb{1})$ & -4.000951 & 2.651528 & -1.492053 & 0.11469 \\
\hline
\end{tabular}

Tabel .7.

\section{Kesimpulan Hipotesis}

\begin{tabular}{|c|c|c|c|c|c|}
\hline II & 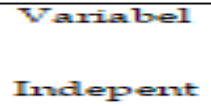 & $\begin{array}{l}\text { Waniabel } \\
\text { Dependen }\end{array}$ & 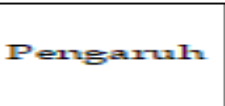 & Silemifillan. & II I $=$ il \\
\hline III & $\begin{array}{l}\text { SUTSID } \\
\text { YIDIR }\end{array}$ & 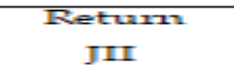 & Plositif & Silendifillan & $\begin{array}{c}\text { Di } \\
\text { teningn: }\end{array}$ \\
\hline$I I \geq$ & $\begin{array}{l}\text { ACTIS } \\
\text { AIDIR }\end{array}$ & $\begin{array}{l}\text { Rtetion 177. } \\
\text { JIII }\end{array}$ & Prositif & Sileguifillan & $\begin{array}{c}\text { Di } \\
\text { tentingen }\end{array}$ \\
\hline 113 & $A T_{n+1}=\mathrm{i}$ & $\begin{array}{c}\text { RAetranit } \\
\text { JIII }\end{array}$ & Wesatif & Silenifillan & $\begin{array}{c}\text { Dii } \\
\operatorname{tolin} 1:\end{array}$ \\
\hline $\mathbb{I}=1$ & AMNII & $\begin{array}{c}\text { REetranzi } \\
\text { JIII }\end{array}$ & Prositif & Silelvifillan. & $\begin{array}{c}\text { Dii } \\
\text { tenimann }\end{array}$ \\
\hline Ins & $\Delta \Pi \subset \mathbb{P}$ & $\begin{array}{c}\text { Retran } \\
\text { JII }\end{array}$ & $\mathbb{W}=$ sentif & 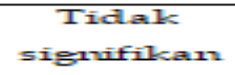 & $\begin{array}{c}\text { Dii } \\
\operatorname{talin} 1:\end{array}$ \\
\hline II 16 & $\begin{array}{l}\text { ANIalano } \\
\text { elopitumi }\end{array}$ & $\begin{array}{c}\text { REetrancin } \\
\text { IIII }\end{array}$ & Pronitif & Silgruifilemin. & $\begin{array}{c}\text { Dii } \\
\text { texingum }\end{array}$ \\
\hline
\end{tabular}

\section{KESIMPULAN}

Menjadi tantangan besar bagi ekonom dan investor untuk menguji seberapa besar pengaruh antara perubahan variabel-variabel akibat sentimen yang terjadi dengan indeks saham syariah. Selain itu, pasar modal syariah menambah alternatif para pemilik modal yang kelebihan dananya untuk menanamkan dana tersebut dalam produk yang berbasis syariah. Salah satu produk syariah yang diluncurkan pasar modal yaitu saham syariah (Ega Risti Safany dkk, 2021). Tujuan utama penelitian ini adalah untuk menambah nilai literasi terhadap indeks syariah, dengan menganalisis perubahan-perubahan yang terjadi dalam makroekonomi diakibatkan oleh sentimen perang dagang 
yang terjadi. Hasil penelitian menunjukan bahwa mayoritas residual dalam penelitian merespon guncangan diberbagai tingkat, akan tetapi guncangan tersebut terjadi bervariatif tidak mengarah pada satu trend tertentu. Untuk itu diperlukan kebijakan dalam jangka pendek bagi perusahaan dan bagi pemerintah untuk merangsang pertumbuhan investor dalam pasar saham syariah.

\section{IMPLIKASI PENELITIAN}

Implikasi pada penelitian ini yaitu untuk melihat Fluktuasi kondisi makro ekonomi akibat sentimen perang dagang global yang telah telah menunjukan pengaruh yang nilai signifikansinya sangat tinggi, karenanya diperlukan diagnostik lebih mendalam terhadap fenomena tersebut.

\section{REFERENSI}

Adiningtyas, D. T. (2018) ‘Pengaruh Variabel Makroekonomi Terhadap Indeks Harga Saham Syariah (Studi Kasus Di Indonesia Dan Malaysia)', ISLAMICONOMIC: Jurnal Ekonomi Islam, 9(2), pp. 151-172. doi: 10.32678/ijei.v9i2.91.

Aghekyan-Simonian, M. et al. (2012) 'The role of product brand image and online store image on perceived risks and online purchase intentions for apparel', Journal of Retailing and Consumer Services, 19(3), pp. 325-331. doi: 10.1016/j.jretconser.2012.03.006.

Aisiyah, S. S. (2013) 'Analisis Dampak Variabel Makro Ekonomi Terhadap Indeks Saham Syariah Indonesia', pp. 398-412.

Auliyah, R. and dan Hamzah, A. (2006) 'Analisa karakteristik perusahaan, industri dan ekonomi makro terhadap return dan beta saham syariah di Bursa Efek Jakarta', Sna, Vol I(23-26 Agustus), p. 16.

Baghestani, H. and AbuAl-Foul, B. (2010) 'Factors influencing Federal Reserve forecasts of inflation', Journal of Economic Studies, 37(2), pp. 196-207. doi: 10.1108/01443581011043582. 
Bala, U. and Chin, L. (2017) 'Oil Price, Exchange Rate and Disaggregate Consumer Prices: Causality, Impulse Response, and Variance Decomposition', International Journal of Economics, Commerce and Management, V(6), pp. 37-59.

Barakat, M. R., Elgazzar, S. H. and Hanafy, K. M. (2015) 'Impact of Macroeconomic Variables on Stock Markets: Evidence from Emerging Markets', International Journal of Economics and Finance, 8(1), p. 195. doi: 10.5539/ijef.v8n1p195.

Beckmann, J., Belke, A. and Kühl, M. (2011) 'The dollar-euro exchange rate and macroeconomic fundamentals: A time-varying coefficient approach', Review of World Economics, 147(1), pp. 11-40. doi: 10.1007/s10290-010-0074-6.

BenMabrouk, H. (2018) 'Cross-herding behavior between the stock market and the crude oil market during financial distress: Evidence from the New York stock exchange', Managerial Finance, 44(4), pp. 439-458. doi: 10.1108/MF-092017-0363.

Ciner, C. (2013) 'Oil and stock returns: Frequency domain evidence', Journal of International Financial Markets, Institutions and Money. Elsevier B.V., 23(1), pp. 1-11. doi: 10.1016/j.intfin.2012.09.002.

Gupta, R. and Reid, M. (2013) 'Macroeconomic surprises and stock returns in South Africa', Studies in Economics and Finance, 30(3), pp. 266-282. doi: 10.1108/SEF-Apr-2012-0049.

Hsing, Y. (2008) 'The impacts of the stock price and country risk on the exchange rate in Singapore', International Journal of Development Issues, 7(1), pp. 56-61. doi: 10.1108/14468950810880026.

Hull, B. (2002) 'A structure for supply chain information flows and its application to the Alaskan crude oil supply chain', Logistics Information Management, 15(1), pp. 8-23. doi: 10.1108/09576050210412639.

Hussin, M. Y. M. et al. (2013) 'The Link Between Gold Price, Oil Price and Islamic Stock Market: Experience from Malaysia', Journal of Studies in Social Sciences, 4(2), pp. 161-182. Available at: 
https://www.researchgate.net/publication/306536880.

Kurihara, Y. (2012) 'Exchange rate determination and structural changes in response to monetary policies', Studies in Economics and Finance, 29(3), pp. 187-196. doi: 10.1108/10867371211246858.

Law, S. H. and Ibrahim, M. H. (2014) 'The response of sectoral returns to macroeconomic shocks in the Malaysian stock market', Malaysian Journal of Economic Studies, pp. 183-199.

Li, Z. and Zhao, H. (2011) 'Not all demand oil shocks are alike: Disentangling demand oil shocks in the crude oil marke', Journal of Chinese Economic and Foreign Trade Studies, 4(1), pp. 28-44. doi: 10.1108/175444401111106798.

Lin, C. C., Fang, C. R. and Cheng, H. P. (2010) ‘Relationships between oil price shocks and stock market: an empirical analysis from Greater China', China Economic Journal, 3(3), pp. 241-254. doi: 10.1080/17538963.2010.562031.

Montes, G. C. and Nicolay, R. T. da F. (2015) 'Central bank's perception on inflation and inflation expectations of experts', Journal of Economic Studies, 42(6), pp. 1142-1158. doi: 10.1108/jes-07-2014-0116.

Musthafa, M. (2017) 'Analisis Pengaruh Faktor Ekonomi Makro Terhadap Harga Saham Pada Perusahaan Manufaktur Yang Go Public Di Bursa Efek Indonesia', EKUITAS (Jurnal Ekonomi dan Keuangan), 13(1), p. 1. doi: 10.24034/j25485024.y2009.v13.i1.2102.

Nguyen, T. (2011) 'US macroeconomic news spillover effects on Vietnamese stock market', Journal of Risk Finance, 12(5), pp. 389-399. doi: $10.1108 / 15265941111176127$.

Payne, J. E. (2008) 'Inflation and inflation uncertainty: Evidence from the Caribbean region', Journal of Economic Studies, 35(6), pp. 501-511. doi: 10.1108/01443580810916523.

Schnabel, J. A. (2011) ‘Deriving competitive advantage from real exchange rate changes', Competitiveness Review, 21(3), pp. 322-327. doi: 10.1108/10595421111134886.

Widad, M. and Hadjer, B. (2018) 'Causal Relationship Between Islamic Bonds, 
Oil Price and Precious Metals: Evidence From Asia Pacific', Al-Iqtishad: Jurnal Ilmu Ekonomi Syariah, 10(2), pp. 285-298. doi: 10.15408/aiq.v10i2.7171. $\mathrm{Wu}, \mathrm{L}$. (2012) A new paradigm for inflation derivatives modeling, Contemporary Studies in Economic and Financial Analysis. Emerald Group Publishing Ltd. doi: 10.1108/S1569-3759(2012)0000094015.

Yudianto, I. and Muharam, H. (2018) 'The Effect Of Inflation, USD And Yuan Exchange Rate, Crude Oil WTI and ICP to Indices Sectoral Returns In Indonesian Stock', 27(1).

Zhang, Y. J. and Wu, Y. Bin (2018) 'The dynamic information spill-over effect of WTI crude oil prices on China's traditional energy sectors', China Agricultural Economic Review, 10(3), pp. 516-534. doi: 10.1108/CAER-052017-0094.

Adiningtyas, D. T. (2018). Pengaruh Pengaruh Variabel Makroekonomi Terhadap Indeks Harga Saham Syariah (Studi Kasus Di Indonesia Dan Malaysia). ISLAMICONOMIC: Jurnal Ekonomi Islam, 9(2).

Ardana, Y. (2016). Analisis Pengaruh Variabel Makroekonomi Terhadap Indeks Saham Syariah Indonesia: Periode Mei 2011 - September 2015 Dengan Model ECM. Jurnal Eksekkutif, 13(1).

Prasetyo, Y., Athoillah, M. A., \& Rosadi, A. (2019). Pengaruh Variabel Ekonomi Makro (Inflasi, Kurs Rupiah dan Flktuasi Harga Emas Dunia) Terhadap Return Saham Syariah. Istinbath, 18(1).

Tripuspitorini, F. A. (2021). Analisis Pengaruh Inflasi, Nilai Tukar Rupiah, dan BI-Rate terhadap Harga Indeks Saham Syariah Indonesia. Jurnal Maps (Manajemen Perbankan Syariah), 4(2).

Suciningtyas, S. A., \& Khoiroh, R. (2015). Analisis Dampak Variabel Makro Ekonomi Terhadap Indeks Saham Syariah Indonesia (ISSI). In Conference in Business, Accounting And Management (CBAM), vol. 2, no. 1, pp. 398-412. 2015).

Yuniati, H. (2018). Pengaruh Nilai Tukar (Kurs) Dan Tingkat Suku Bunga 
Terhadap Return Saham Syariah Dengan Menggunakan Variabel Intervening Indeks Saham Syariah Indonesia (ISSI) (Studi Kasus Pada Sektor Property Dan Real Estate Periode Desember 2015-Mei 2016). Jurnal Ekobis Dewantara, 1(5).

Artiani, L. E., \& Sari, C. U. P. (2019). Pengaruh Variabel Makro Dan Harga Komoditas Tambang Terhadap Harga Saham Sektor Pertambangan Di Indeks Saham Syariah Indonesia (ISSI). Jurnal Ekonomika, 10(2).

Beik, I. S., \& Fatmawati, S. W. (2014). Pengaruh Indeks Harga Saham Syariah Internasional dan Variabel Makro Ekonomi Terhadap Jakarta Islamic Index. Al-Iqtishad: Jurnal Ilmu Ekonomi Syariah, 6(2).

Chotib, E., \& Huda, N. Analisis Pengaruh Variabel Ekonomi Makro Terhadap Indeks Saham Syariah Indonesia (ISSI) Periode 2016 - 2019. JEBA (Journal of Economics and Business Aseanomics), 4(1).

Rahmawati, F., \& Baini, N. (2020). Dampak Variabel Makro Ekonomi Domestik dan Global Terhadap Indeks Saham Syariah Indonesia (ISSI) Periode Mei 2011-Mei 2019. Li Falah: Jurnal Studi Ekonomi dan Bisnis Islam, 4(2).

Fadila, N., \& Ardini, L. (2019). Pengaruh Variabel Makro Ekonomi Dan Fundamental Terhadap Return Saham Syariah. Jurnal Imu dan Riset Akuntansi (JIRA), 8(5).

Nurrahmawati, H., Mauluddi, H. A., \& Juniwati, E. H. (2021). Analisis Pengaruh Variabel Makro Ekonomi terhadap Nilai Aktiva Bersih Reksadana Saham Syariah Periode 2015-2019. Journal of Applied Islamic Economics and Finance, 1(2).

Safany, E. R., Setiawan, I., \& Tripuspitorini, F. A. (2021). Analisis Pengaruh Makroekonomi dan Kinerja Perusahaan terhadap Harga Saham Syariah pada Indeks Saham Syariah Indonesia. Journal of Applied Islamic Economics and Finance, 2(1).

Nurliandini, N., Juniwati, E. H., \&Setiawan, S. (2021). Analisis Pengaruh Faktor Fundamental, Teknikal dan Makro Ekonomi terhadap Harga Saham pada Perusahaan Subsektor Kimia yang Terdaftar di Indeks Saham Syariah. 
Journal of Applied Islamic Economics and Finance, 2(1).

Fauzan, E., \& Khairunnisa, K. (2020). Analisis Pengaruh Jangka Pendek Dan Jangka Panjang Variabel Makroekonomi Terhadap Return Indeks Saham Syariah Periode 2014-2018. Jurnal Wawasan dan Riset Akuntansi, 7(1).

Nur. S., \& Fatwa, N. (2022). Analisis Pengaruh Indikator Makroekonomi Terhadap Indeks Saham Syariah Indonesia. Jurnal Tabarru' Islamic Banking and Finance, 5(1).

Firdausi, A. N., Fahmi, I., \& Saptono, I. T. (2016). Pengaruh Indeks Harga Saham Regional ASEAN dan Variabel Makroekonomi terhadap Indeks Harga Saham Syariah Indonesia (ISSI). Al-Muzara'ah, 4(2).

Sudarsono, H. (2018). Indikator Makroekonomi dan Pengaruhnya Terhadap Indeks Saham Syariah Indonesia. Esensi Jurnal Bisnis dan Manajemen, 8(2).

Rachmawati, M., \& Laila, N. (2015). Faktor Makroekonomi Yang Mempengaruhi Pergerakan Harga Saham Pada Indeks Saham Syariah Indonesia (ISSI) Di Bursa Efek Indonesia (BEI). Jurnal Ekonomi Syariah Teori dan Terapan, 2(11).

Zaimsyah, A. M., Ayun, A. A., Rofi'ah, K., \& Herianingrum, S. (2020). Pengaruh Variabel Makroekonomi Terhadap Index Harga Saham Syariah. Jurnal Ekonomi 